\section{Antimicrobial Mitigation via Saponin Intervention on Escherichia coli and Growth and Development of Hydroponic Lettuce}

\author{
Nathan J. Eylands ${ }^{1}$, Michael R. Evans ${ }^{2}$, and Angela M. Shaw ${ }^{3}$
}

ADDITIONAL INDEX WORDS. bactericide, foodborne diarrheal disease

SUMmARY. Various saponins have demonstrated allelochemical effects such as bactericidal impacts as well as antimycotic activity against some plant pathogenic fungi, thereby acting to benefit plant growth and development. A commercial saponin solution was evaluated for bactericidal effects against Escherichia coli and growth of lettuce (Lactuca sativa) in a hydroponic system. E. coli $(\mathrm{P} 4, \mathrm{Pl3}$, and P68) inoculum at final concentration of $10^{8}$ colony-forming units $(\mathrm{cfu}) / \mathrm{mL}$ was added to $130 \mathrm{~L}$ of a fertilized solution recirculating in a nutrient film technique (NFT) system used to grow 'Rex' lettuce. After 5 weeks in the NFT system, E. coli populations were lowest in the inoculated treatment that did not contain any saponin addition $(0.89 \mathrm{log}$ $\mathrm{cfu} / \mathrm{mL})$ when compared with all other inoculated treatments $(P<0.001)$. The treatment containing $100 \mu \mathrm{g} \cdot \mathrm{mL}^{-1}$ saponin extract had an $E$. coli population of $4.61 \log \mathrm{cfu} / \mathrm{mL}$ after 5 weeks that was higher than treatments containing 25 $\mu \mathrm{g} \cdot \mathrm{mL}^{-1}$ or less $(P<0.0001)$. Thus, higher $E$. coli populations were observed at higher saponin concentrations. Plant growth was also inhibited by increasing saponin concentrations. Fresh and dry shoot weight were both higher in the inoculated and uninoculated treatments without the saponin addition after 5 weeks in the NFT system $(P<0.0001)$. Lettuce head diameter was smaller when exposed to saponin treatments with concentrations of 50 and $100 \mu \mathrm{g} \cdot \mathrm{mL}^{-1}(P<0.0001)$. Lettuce leaves were also tested for the potential of $E$. coli to travel systemically to the edible portions of the plant. No E. coli was found to travel in this manner. It was concluded that steroidal saponins extracted from mojave yucca ( Yucca schidigera) are not an acceptable compound for use in mitigation of $E$. coli in hydroponic fertilizer solution due to its ineffectiveness as a bactericide and its negative impact on lettuce growth.

$\mathrm{E}$ very year, 48 million Americans become infected from a foodborne disease; 128,000 of whom require hospitalization resulting in 3000 deaths [Centers for Disease Control and Prevention (CDC), 2019b]. Although healthy foods are an important part of a well-rounded diet, there are concerns, as fruits, vegetables, and nuts accounted for $23 \%$ of reported human foodborne illness outbreaks between

Received for publication 7 Oct. 2020. Accepted for publication 28 Dec. 2020.

Published online 28 January 2021

${ }^{1}$ Horticulture Section, College of Agriculture and Life Sciences, Cornell University, 135 Plant Science Building, Ithaca, NY 14853

${ }^{2}$ School of Plant and Environmental Sciences, Virginia Polytechnic Institute and State University, 328 Smyth Hall, Blacksburg, VA 24061

${ }^{3}$ Department of Food Science and Human Nutrition, Iowa State University, 2577 Food Sciences Building, Ames, IA 50011

N.J.E. is the corresponding author. E-mail: nje9@ cornell.edu.

This is an open access article distributed under the $\mathrm{CC}$ BY-NC-ND license (https://creativecommons.org/ licenses/by-nc-nd/4.0/).

https://doi.org/10.21273/HORTTECH04749-20
2009 and 2015 (CDC, 2017a, $2017 \mathrm{~b}$ ). Escherichia coli is one of the most prominent causes of foodborne diarrheal disease in humans. It is also a leading contributor to bacterial infections and extraintestinal infections in humans and animals alike (Njage and Buys, 2014). A primary source of E. coli infection in the United States is through contaminated agricultural products. In 2019, the CDC reported two multistate outbreaks related to $E$. coli O157:H7 in leafy greens (CDC, 2019a).

Controlled environment agriculture (CEA) production facilities, such as greenhouses and plant factories, present advantages over traditional field production, such as crop space efficiency and year-round growth, and they also provide a reduced risk for food safety issues (Holvoet et al., 2015). Although contamination risks are reduced in CEA, they are not eliminated (Orozco et al., 2008) and therefore water quality used for irrigating crops is a concern, as contaminated source water (municipal, holding pond, or well) or fertilizer solution can splash onto crops during production and harvesting, leading to E. coli infection in humans (Solomon et al., 2003). Additional risks within CEA pre- and postharvest production include pest and wild animal management, planting substrates, unsanitary equipment and buildings, and human handling (Holvoet et al., 2015).

Within CEA, an operational choice of production system establishes the likelihood of microbial spread in the event of contamination. Hydroponic production is a popular practice among CEA producers, adding greater efficiency and control to their cultivation processes over traditional farming practices. E. coli exhibits the ability to thrive in fertilizer solutions in a hydroponic system (Shaw et al., 2016). This presents a unique problem for growers who use a recirculating hydroponic system. Because a fertilizer solution is collected and recycled through irrigation lines, a microbial contaminant has the potential to infect not some, but the entire crop, continually recycling a solution of pathogens (Premuzic et al., 2007).

Although contamination potential remains low in CEA, preventive measures to disinfest source water must be a focal point for food safety and public health. Cultural practices, such as personal hygiene and sick employee protocols, will always remain an important area in produce production, but further disinfestation

\begin{tabular}{llll}
\hline $\begin{array}{l}\text { Units } \\
\begin{array}{l}\text { To convert U.S. to SI, } \\
\text { multiply by }\end{array}\end{array}$ & U.S. unit & SI unit & $\begin{array}{l}\text { To convert SI to U.S., } \\
\text { multiply by }\end{array}$ \\
\hline 29,574 & $\mathrm{fl} \mathrm{oz}$ & $\mu \mathrm{L}$ & $3.3814 \times 10^{-5}$ \\
29.5735 & $\mathrm{fl} \mathrm{oz}$ & $\mathrm{mL}$ & 0.0338 \\
3.7854 & $\mathrm{gal}$ & $\mathrm{L}$ & 0.2642 \\
2.54 & inch $(\mathrm{es})$ & $\mathrm{cm}$ & 0.3937 \\
1 & $\mathrm{mmho} / \mathrm{cm}$ & $\mathrm{dS} \cdot \mathrm{m}^{-1}$ & 1 \\
1 & $\mathrm{ppm}$ & $\mathrm{mg} \cdot \mathrm{L}^{-1}$ & 1 \\
1 & $\mathrm{ppm}$ & $\mu \mathrm{g} \cdot \mathrm{mL}^{-1}$ & 1 \\
$\left({ }^{\circ} \mathrm{F}-32\right) \div 1.8$ & ${ }^{\circ} \mathrm{F}$ & ${ }^{\circ} \mathrm{C}$ & $\left({ }^{\circ} \mathrm{C} \times 1.8\right)+32$
\end{tabular}


measures will help safeguard a crop to be free of microbial pathogens like $E$. coli. Current techniques used to mitigate microbial pathogens can be effective but have cost and complexity limitations that prohibit their use to many farmers. Ultraviolet radiation is effective and widely used; however, small pathogens may pass by the light waves in the shadow of debris and remain active, therefore filtration of the water and cleaning of the ultraviolet lamp (Garibaldi et al., 2004) are paramount to this method's usefulness. Biofiltration may reduce pathogens, but does not eliminate them (Belbahri et al., 2007; Wohanka, 1995). Chlorination may cause phytotoxic symptoms to plants (Premuzic et al., 2007) and produce the byproduct trihalomethane, which is classified by the U.S. Environmental Protection Agency as a potential human carcinogen (Symons et al., 1981).

Natural antimicrobials are becoming more prevalent among microbial disinfestation methods in the food industry (Zhu et al., 2015). Plant-based isolated compounds contain secondary metabolites that are known to retard or inhibit the growth of bacteria, yeasts, and molds (Tiwari et al., 2009). Saponins are secondary metabolites widely distributed throughout the plant kingdom and have been documented to exhibit natural antibacterial properties (Lokesh et al., 2016; Wallace, 2004). Saponins are nonionic detergents that have an assortment of biological properties. Their structure is composed of a steroidal or triterpenoid aglycone skeleton attached to one or more sugar chains (Arabski et al., 2011). This diversity in structure is what leads to the great diversity in biological properties. Beyond their bactericidal functions, saponins also display antifungal, hemolytic, membrane-depolarizing, ammoniabinding, antiyeast, antimold (Arabski et al., 2011; Oleszek, 1996), and many other natural biological properties. Their effects are generally credited to their ability to permeate cellular membranes (Francis et al., 2002).

The following study was conducted to investigate the antimicrobial properties of steroidal saponins extracted from mojave yucca ( $Y$ ucca schidigera) on gram-negative E. coli in a hydroponic fertilizer solution over time. In addition, the growth and development of lettuce (Lactuca sativa) grown in an NFT hydroponic system was evaluated for yield parameters.

\section{Materials and methods}

STERILITY OF COMPONENTS. Before each replication, all materials (lettuce seedlings, municipal tap water, and hydroponic equipment) used in this study were analyzed (using the same enumeration protocol in the section "Data Collection and Bacterial Enumeration") and found to be negative for the presence of $E$. coli cfu (data not shown; detection limit was $100 \mathrm{cfu} / \mathrm{mL})$.

BACTERIAL Cultures. Individual isolates of nonpathogenic E. coli (P4, P13, and P68) were obtained from the culture collection of the Microbial Food Safety Laboratory, Iowa State University, Ames, IA. Isolate selections were based on behavioral similarities to E. coli O157:H7 (Marshall et al., 2005). All strains were adapted to grow in the presence of $80 \mu \mathrm{g} \cdot \mathrm{mL}^{-1}$ rifampicin (Thermo Fisher Scientific, Waltham, MA), through stepwise exposure (Parnell et al., 2005). Parnell procedure: Briefly, $100 \mu \mathrm{L}$ of an overnight culture was spread onto plate count agar containing antibiotic. After incubation for $24 \mathrm{~h}$ at $37^{\circ} \mathrm{C}$, isolated colonies were selected from the plate containing the highest level of antibiotic and cultured overnight in nutrient broth. This procedure was repeated until a variant resistant to 80 $\mu \mathrm{g} \cdot \mathrm{mL}^{-1}$ rifampicin was obtained. Growth curves of the parent and variant strains were similar in tryptic soy broth (Difco Laboratories, Detroit, MI) (data not shown). Bacterial strains were subsequently combined into a cocktail suspended in a cryoprotective glycerol solution and stored at $-21{ }^{\circ} \mathrm{C}$. Frozen cultures were thawed in cold water, diluted 1:10 in buffered peptone water (BPW), and incubated at $37^{\circ} \mathrm{C}$ for 24 $\mathrm{h}$ to yield a population of $\approx 10^{8} \mathrm{cfu} /$ $\mathrm{mL}$. The resulting solution was used to inoculate irrigation water in the following experiment.

LETTUCE GROWING CONDITIONS, INOCULATION, AND SAPONIN SOLUTION. Under ambient greenhouse light, foam hydroponic seed germination media (276-cell count Horticubes; Smithers Oasis, Kent, $\mathrm{OH}$ ) was placed in sub-irrigated hydroponic propagation trays (American Hydroponics, Arcata, CA), where they were leached, and seeded with 'Rex' lettuce (Johnny's Selected Seeds, Winslow, ME). Greenhouse temperature setpoints were set to cool at $21{ }^{\circ} \mathrm{C}$ and heat at $18{ }^{\circ} \mathrm{C}$. Average recorded daily light integral across all experimental replications was $18 \mathrm{~mol} \cdot \mathrm{m}^{-2} \cdot \mathrm{d}^{-1}$. Before seedling transplantation, six separate NFT systems were filled with $130 \mathrm{~L}$ tap water and allowed to recirculate for $24 \mathrm{~h}$. At this point, selected systems were inoculated with $20 \mathrm{~mL}$ of $E$. coli cocktail to obtain a population of $\approx 10^{4} \mathrm{cfu} /$ $\mathrm{mL}$. Dissolved fertilizer salts and $1 \mathrm{M}$ sulfuric acid $\left(\mathrm{H}_{2} \mathrm{SO}_{4}\right)$ were added to create $130 \mathrm{~L}$ of fertilizer solution with an electrical conductivity of 1.4 $\mathrm{dS} \cdot \mathrm{m}^{-1}$ and a $\mathrm{pH}$ of 5.9 , which was maintained daily in all systems throughout the study. Subsequently, a saponin intervention was added. The saponin product used in this study was supplied in a premixed solution (Micro-Aid Liquid 50; DPI Global, Porterville, CA), and contained sapogenin with a steroidal aglycone structure extracted from mojave yucca. The solution was certified by the Organic Materials Review Institute and contained 14\% saponins. It was supplied to each 130$\mathrm{L}$ irrigation reservoir at treatment rates of $0,12.5,25,50$, or $100 \mu \mathrm{g} \cdot \mathrm{mL}^{-1}$ a.i. Saponin treatments were randomly assigned to each NFT system. The methods reported here were repeated in three experimental replications. System water loss due to transpiration and evaporation was replenished weekly with a commensurate amount of saponin solution. Seedlings were transplanted into the NFT systems at the four-true-leaf stage.

DatA COLLECTION AND BACTERIAL ENUMERATION. Fertilizer solution samples of $25 \mathrm{~mL}$ were taken at $\mathrm{l} \mathrm{h}$ after inoculation and then 1 , $168,336,504,672$, and $840 \mathrm{~h}$ after saponin intervention. To ensure a homogeneous sample, $5-\mathrm{mL}$ aliquots were taken from five separate locations within each system: top half of the nutrient reservoir, lower half of the nutrient reservoir, drain collector, NFT channel, and dripper emitter. These samples were used to evaluate viable E. coli populations in each NFT system.

Enumeration of E. coli populations was determined by serial dilutions using BPW as the dilution 
solution. Dilutions were plated on MacConkey agar $(0.1 \%$ rifampicin $)$ containing a tryptic soy agar (TSA) overlay using a spread plate technique. Plates were incubated at $37^{\circ} \mathrm{C}$ for $24 \mathrm{~h}$ before manual counts. Presence of rifampicin was to ensure bacteria were accurately detected in the presence of high natural flora.

Five lettuce plants were selected using a random number generator and collected for analysis from each treatment after 5 weeks $(840 \mathrm{~h})$ posttransplant into the NFT systems. The first three plants selected were evaluated for growth characteristics and the subsequent two plants were tested for the presence of E. coli.

Plants that had been designated for measuring growth characteristics were weighed immediately to determine fresh shoot weight on a digital balance (AP250D; Ohaus, Parsippany, $\mathrm{NJ})$. Lettuce plant diameter was measured at the widest point before plants were placed inside a paper bag and into an oven. Plants were heated at $70{ }^{\circ} \mathrm{C}$ for $2 \mathrm{~d}$ to fully desiccate before obtaining dry weights.

Plants that had been designated to be tested for $E$. coli presence were harvested as described earlier and then immediately transferred into $14 \times 19$-inch sterile sample bags (Nasco, Fort Atkinson, WI). Plant weight was determined using a digital balance (AP250D) to create a $1: 10$ $(\mathrm{w} / \mathrm{v})$ dilution with deionized water. The bag contents were then manually stomached to suspend internal microorganisms. The resulting solution was used to determine presence or absence of E. coli on or within the edible portions of the lettuce leaves by the enumeration techniques described previously.

Statistical analysis. Quantification of E. coli concentration samples were $\log \left(\log _{10}\right)$ transformed before analysis. Each sample was unilaterally increased by one to prevent syntax error to any zero counts. The noninoculated treatment without saponin addition was removed from the analysis due to lack of variability and influence on the remaining dataset. The factorial analysis was performed as a repeated measure using a Student's $t$ test least significant difference to examine mean separation. Plant growth and development data were normalized by examining each measurement as a percentage of the noninoculated treatment without saponin addition mean for that block. A one-way analysis of variance was performed at each time point to evaluate mean differences. Mean separation was determined using a Tukey's honestly significant difference. All analyses were performed using JMP Pro (version 14.0.0; SAS Institute, Cary, NC).

\section{Results}

EFFECTS OF SAPONINS ON GROWTH OF $\boldsymbol{E}$. COLI. Lettuce plants that were evaluated for the presence of $E$. coli every week were not found to have any recoverable populations compartmentalized within the edible portions of the plant (data not shown). The timing of treatment and treatment itself were significant effects in the analysis $(P<0.0001, P<$ $0.0001)$. Table 1 displays the effects of saponin on $E$. coli at the various time periods. Through the experiment, the treatment with no inoculum and no saponins remained with no recoverable $E$. coli at all time periods. After $\mathrm{l} \mathrm{h}$ from inoculation of the recirculating tap water in the NFT systems, all inoculated treatments had no saponin addition and contained E. coli at 0.6 to $0.83 \mathrm{log}$ $\mathrm{cfu} / \mathrm{mL}(P=0.74)$.

After $2 \mathrm{~h}$ from inoculation ( $1 \mathrm{~h}$ from the saponin addition), all inoculated treatments containing a saponin addition had similar amounts of $E$. coli between the treatment levels $[<0.001-1.11$ log $\mathrm{cfu} / \mathrm{mL} \quad(P=$ $0.57)]$.

After $168 \mathrm{~h}$ (1 week) from the saponin addition, all treatments increased $E$. coli cfus by at least $2 \operatorname{logs}$ (2.49-5.28 $\log \mathrm{cfu} / \mathrm{mL})$ and were different $(P=0.001)$. The inoculated treatment without saponin (2.49 log $\mathrm{cfu} / \mathrm{mL}$ ) was similar to the treatments with saponin concentrations of 12.5 and $25 \mu \mathrm{g} \cdot \mathrm{mL}^{-1}$, which had 3.57 and $3.7 \log \mathrm{cfu} / \mathrm{mL}$, respectively. Similarly, the treatments with the highest concentrations of saponin (50 and $100 \mu \mathrm{g} \cdot \mathrm{mL}^{-1}$ ) yielded the highest amount of $E$. coli ranging from 5.08 to $5.28 \log \mathrm{cfu} / \mathrm{mL}$, which were similar results.

Treatment differences persisted after 336 h ( 2 weeks) from the saponin addition $(P=0.0001)$. The inoculated treatment without saponin had $2.17 \log \mathrm{cfu} / \mathrm{mL}$, which was similar to the other treatments with saponin concentrations of 12.5 and $25 \mu \mathrm{g} \cdot \mathrm{mL}^{-1}$ (3.3 and $3.45 \mathrm{log} \mathrm{cfu} /$ $\mathrm{mL})$. The inoculated treatments containing saponin concentrations of 50 and $100 \mu \mathrm{g} \cdot \mathrm{mL}^{-1}$ had the highest yields of $E$. coli populations with 5.02 and $5.61 \log \mathrm{cfu} / \mathrm{mL}$, respectively, and were different from all other treatments.

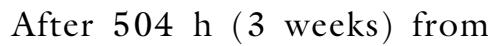
the saponin addition, differences remained $(P=0.0001)$. The inoculated treatment without saponin experienced a reduction in $E$. coli population from the previous week to $1.53 \log \mathrm{cfu} / \mathrm{mL}$, which was lower than all other inoculated treatments. The inoculated treatment containing a saponin concentration of 12.5 $\mu \mathrm{g} \cdot \mathrm{mL}^{-1}$ had $3.48 \log \mathrm{cfu} / \mathrm{mL}$ and was similar to the inoculated treatments with saponin additions of 25 and $50 \mu \mathrm{g} \cdot \mathrm{mL}^{-1}$, but not to the treatment with a saponin concentration of $100 \mu \mathrm{g} \cdot \mathrm{mL}^{-1}$. The inoculated treatment with a saponin concentration of $100 \mu \mathrm{g} \cdot \mathrm{mL}^{-1}$ had a slight reduction in E. coli population from the previous week, yet still carried the highest amount at the 3 -week time period with $5.23 \log \mathrm{cfu} / \mathrm{mL}$.

After $672 \mathrm{~h}$ (4 weeks) from the saponin addition, treatment differences persisted $(P=0.0001)$. The inoculated treatment without saponin reduced in population to $0.89 \mathrm{log}$ $\mathrm{cfu} / \mathrm{mL}$, which was lower and different from all other treatments. The inoculated treatments with saponin additions of 12.5 and $25 \mu \mathrm{g} \cdot \mathrm{mL}^{-1}$ contained $E$. coli populations of 2.84 and $2.91 \log \mathrm{cfu} / \mathrm{mL}$, respectively. These treatments experienced a reduction for the first time and were also similar to each other. The inoculated treatments with saponin additions of 50 and $100 \mu \mathrm{g} \cdot \mathrm{mL}^{-1}$ had populations of E. coli at 4.39 and 4.77 $\log \mathrm{cfu} / \mathrm{mL}$, which were similar to one another and different from treatments containing saponins at concentrations of $25 \mu \mathrm{g} \cdot \mathrm{mL}^{-1}$ or lower.

At the final time point, $840 \mathrm{~h} \mathrm{(5}$ weeks) from the saponin addition, treatment differences remained $(P=$ $0.0001)$. The inoculated treatment without saponin maintained a low population $(0.89 \log \mathrm{cfu} / \mathrm{mL})$, whereas inoculated treatments containing lower saponin concentrations of 12.5 and $25 \mu \mathrm{g} \cdot \mathrm{mL}^{-1}$ reduced in recoverable $E$. coli populations and were similar to the inoculated 
Table 1. Comparison of Escherichia coli colony-forming unit (cfu) grown in hydroponic fertilizer solution with 0 , 12.5, 25, 50 , and $100 \mu \mathrm{g} \cdot \mathrm{mL}^{-1}(\mathrm{ppm})$ saponin treatment over time.

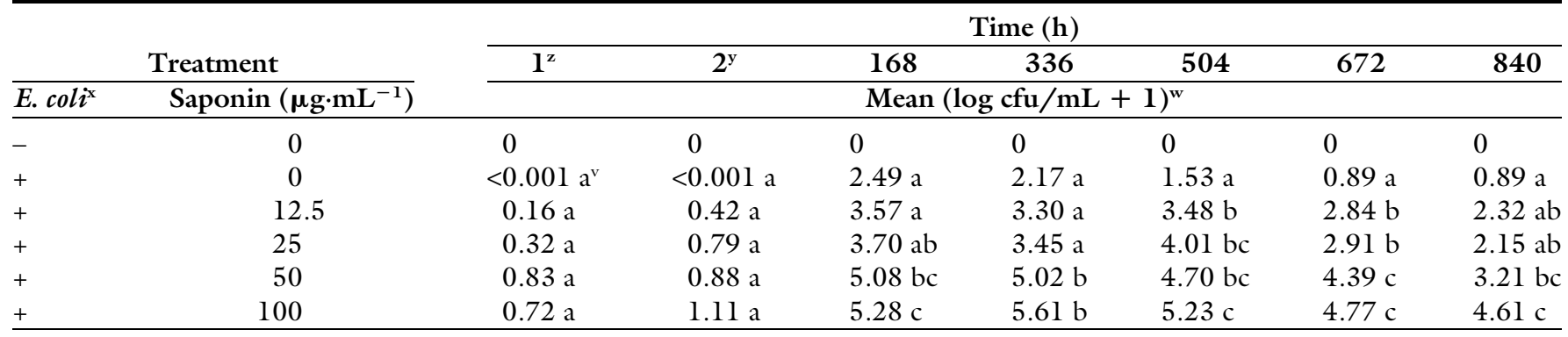

${ }^{\mathrm{z}}$ Saponin treatment intervention not yet applied.

${ }^{\mathrm{y}}$ Enumeration occurred $1 \mathrm{~h}$ post saponin treatment intervention.

${ }^{x}$ Positive $(+)$ indicates presence of $E$. coli inoculated at an initial population of $10^{3} \mathrm{cfu} / \mathrm{mL}$, negative $(-)$ indicates $E$. coli not present. ${ }^{\mathrm{w}}$

${ }^{\mathrm{w}} \mathrm{l} \mathrm{cfu} / \mathrm{mL}=29.5735 \mathrm{cfu} / \mathrm{fl} \mathrm{oz}$.

${ }^{\mathrm{v}}$ Means with different letter(s) are significantly different using a Student's $t$ test at $P \leq 0.05$. All data were pooled from three replications with two subsamples each $(\mathrm{n}=6$ ).

treatment without saponin and contained populations that ranged from 2.15 to $2.32 \log \mathrm{cfu} / \mathrm{mL}$. The inoculated treatments with saponin additions of 50 and $100 \mu \mathrm{g} \cdot \mathrm{mL}^{-1}$ also contained lower amounts of E. coli, yet were higher than other treatments with 3.21 and $4.61 \mathrm{log} \mathrm{cfu} / \mathrm{mL}$ and were similar to one another.

EFFECTS OF SAPONINS ON PLANT GROWTH AND DEVELOPMENT. After 840 h (5 weeks) in the NFT system, the noninoculated treatment that did not contain saponins and the inoculated treatment that did not contain saponins were the highest in terms of fresh shoot weight and dry shoot weight (Table 2 ) and were only similar to the inoculated treatment with a saponin addition of $25 \mu \mathrm{g} \cdot \mathrm{mL}^{-1}(P<$ 0.0001 and $P<0.0001$, respectively). The inoculated treatment containing a saponin concentration of 12.5 $\mu \mathrm{g} \cdot \mathrm{mL}^{-1}$ was similar in fresh and dry shoot weight to the treatment with $25 \mu \mathrm{g} \cdot \mathrm{mL}^{-1}$ of saponins. The inoculated treatment with a saponin addition of $50 \mu \mathrm{g} \cdot \mathrm{mL}^{-1}$ had lower fresh and dry shoot weight than the lower concentrations of saponins; however, it had a higher fresh and dry shoot weight than the inoculated treatment with a saponin addition of $100 \mu \mathrm{g} \cdot \mathrm{mL}^{-1}$.

Lettuce head diameter after 840 h ( 5 weeks) was larger among the noninoculated treatment without saponins and the inoculated treatment without saponins (Table 2). However, they were similar $(P<0.0001)$ to the two inoculated treatments with the lower levels of saponins (12.5 and $25 \mu \mathrm{g} \cdot \mathrm{mL}^{-1}$ ). The inoculated treatment with a saponin addition of $50 \mu \mathrm{g} \cdot \mathrm{mL}^{-1}$ had a smaller head diameter than the treatments with no saponins and lower-level saponins. The inoculated treatment with a saponin addition of $100 \mu \mathrm{g} \cdot \mathrm{mL}^{-1}$ had a head diameter that was smaller than all other treatments evaluated.

\section{Discussion}

Saponin concentration had the most influential effect on growth of E. coli. Over time, all treatments exhibited growth and decline (Fig. I). The rate of growth and decline were affected by the presence and level of the saponin treatment. The experimental hypothesis was that saponins would have an antibacterial effect on $E$. coli. This would suggest that more saponins would equate to less E. coli. The resulting outcome of the experiment was the opposite. The greatest population of $E$. coli was consistently found in the inoculated treatment containing the highest concentration of saponins. At its highest population (336 h), this treatment produced $3 \mathrm{log}$ increases over treatment 2 , which contained no saponin addition. This result was reliably seen at every time point beyond the initial first hours of the experiment.

These results were consistent with those found in the work of Arabski et al. (2011) on triterpenoid saponins who also observed an enhancement of $E$. coli growth when exposed to saponins. The current experiment was conducted using steroidal saponins extracted from mojave yucca found in the southwest United States and northwest Mexico. As discussed previously in this article, the aglycone structure of each saponin compound determines its biological properties. Using the results from this study and those found by Arabski et al. (2011), both steroid and triterpenoid saponins react similarly to stimulate the growth of E. coli. The leading postulate to the reasoning of increased bacterial growth is that saponins increase cell permeability and the influx of nutrients (Arabski et al., 2011). Instead of opening intercellular space to potentially harmful

Table 2. Mean fresh and dry shoot weight and plant diameter of lettuce reported as a percentage of the control grown in a hydroponic fertilizer solution with 0 , $12.5,25,50$, and $100 \mu \mathrm{g} \cdot \mathrm{mL}^{-1}(\mathrm{ppm})$ saponin treatment at time of harvest $(5$ weeks).

\begin{tabular}{|c|c|c|c|c|}
\hline & & \multicolumn{3}{|c|}{ Plant characteristic } \\
\hline \multicolumn{2}{|c|}{ Treatment } & Fresh wt & Dry wt & Diam \\
\hline$\overline{E . \operatorname{coli}^{\mathrm{z}}}$ & Saponin $\left(\mu \mathrm{g} \cdot \mathrm{mL}^{-1}\right)$ & \multicolumn{3}{|c|}{$(\% \text { control })^{\mathrm{y}}$} \\
\hline- & 0 & $100 a^{x}$ & $100 \mathrm{a}$ & $100 \mathrm{a}$ \\
\hline+ & 0 & $101 \mathrm{a}$ & $95 \mathrm{a}$ & $98 \mathrm{a}$ \\
\hline+ & 12.5 & $75 \mathrm{~b}$ & $70 \mathrm{~b}$ & $89 \mathrm{a}$ \\
\hline+ & 25 & $80 \mathrm{ab}$ & $87 \mathrm{ab}$ & $88 \mathrm{a}$ \\
\hline+ & 50 & $44 \mathrm{c}$ & $46 c$ & $74 \mathrm{~b}$ \\
\hline+ & 100 & $14 \mathrm{~d}$ & $16 \mathrm{~d}$ & $48 \mathrm{c}$ \\
\hline
\end{tabular}

${ }^{2}$ Positive (+) indicates presence of Escherichia coli inoculated at an initial population of $10^{3}$ colony-forming units $(\mathrm{cfu}) / \mathrm{mL}$, negative (-) indicates $E$. coli not present; $1 \mathrm{cfu} / \mathrm{mL}=29.5735 \mathrm{cfu} / \mathrm{fl} \mathrm{oz}$.

${ }^{\mathrm{y}}$ Mean responses displayed as percent of noninoculated treatment without saponin (without E. coli, without saponin addition). All data were pooled from three replications with three subsamples each $(n=9)$.

${ }^{x}$ Means with different letter(s) are significantly different using a Tukey's honestly significance difference test at $P \leq 0.05$. 


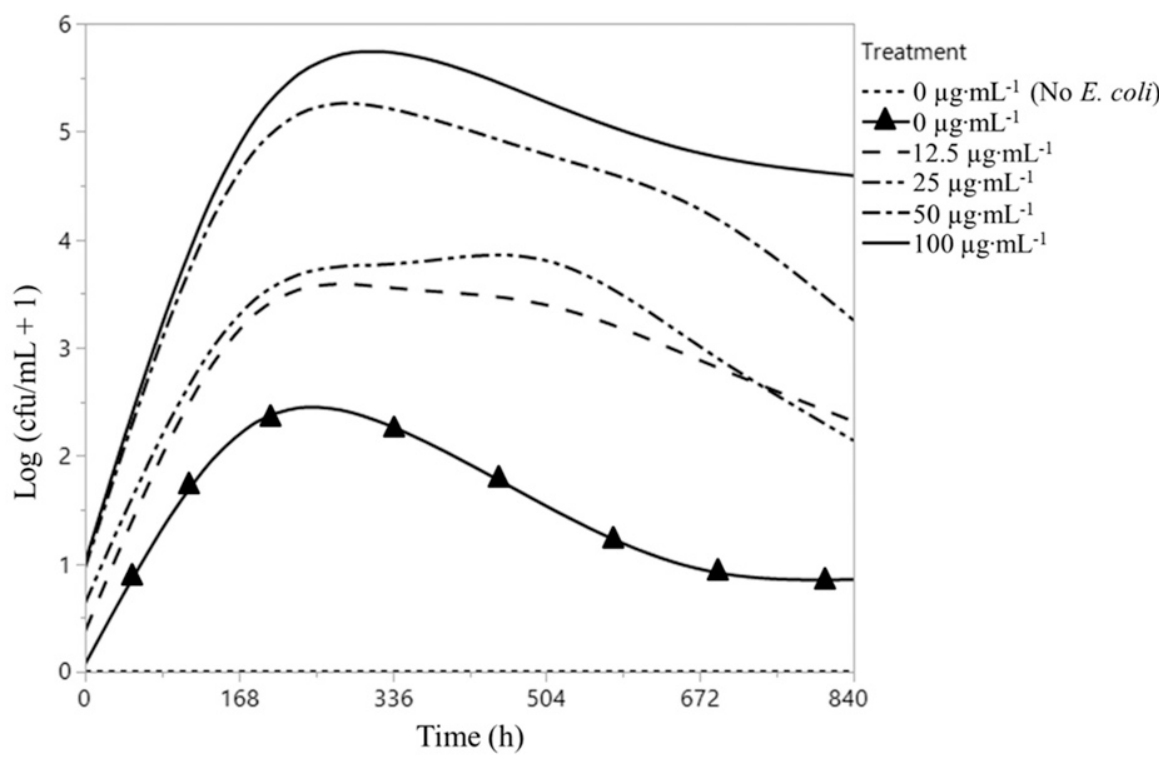

Fig. 1. Growth curves of Escherichia coli populations grown in hydroponic fertilizer solution with $0,12.5,25,50$, and $100 \mu \mathrm{g} \cdot \mathrm{mL}^{-1}$ saponin treatment over time. All data were pooled from three replications with two subsamples each $(\mathbf{n}=$ 6); $1 \mu \mathrm{g} \cdot \mathrm{mL}^{-1}=1 \mathrm{ppm}, 1 \mathrm{cfu} / \mathrm{mL}=29.5735 \mathrm{cfu} / \mathrm{fl} \mathrm{oz}$.

extracellular conditions, newly formed pores in bacterial membranes allow the passage of nutrients to flow into the cell, allowing $E$. coli to prosper.

Another possible explanation to the higher populations of $E$. coli in higher concentrations of saponins revolves around bacterial structure. $E$. coli are gram-negative bacteria, and in research are harder to kill than grampositive bacteria with a peptidoglycan layer. Previous experimenters have elucidated the antibacterial effects of saponins against other gram-negative bacterium (Khan et al., 2018; Mandal et al., 2005). A large difference between those experiments and this experiment is the addition of plants into the system ecology. A plant's rhizosphere can contain up to 100 times the amount of microorganisms found in soil without plants (Haas et al., 2002). This rich biodiversity of microbes is home to a group known as rhizobacteria, which produce beneficial secondary metabolites that enhance plant growth through a variety of mechanisms (Sturz and Christie, 2003). A few notable rhizobacteria are found within the genera Pseudomonas, Streptomyces, and Bacillus (Emmert and Handelsman, 1999; Haas et al., 2002). Brown et al. (1976) were able to isolate naturally occurring sulfur-containing carboxylic acids from strains of Streptomyces, which are very potent inhibitors of $E$. coli. Soetan et al. (2006) reported that saponins only produced inhibitory effects on gram-positive bacteria, contrary to Khan et al. (2018) and Mandal et al. (2005). As previously noted, E. coli are gram-negative; however, Streptomyces is a gram-positive bacterium, leading the investigator in the current study to postulate that higher saponin concentrations inhibited beneficial rhizobacteria like Streptomyces, which allowed E. coli to survive in a less-competitive environment.

It is important to note that early time points in this experiment had very low populations of $E$. coli to report. A study by Cooper et al. (2001) involving E. coli thermal dependence also indicated that most bacterial loss was seen in early stages of the experiment, when adaptation is the most rapid. Bacterial injury was observed on a great deal of the TSA plates. Typical colony morphology appeared circular, convex, and smooth. E. coli that were recovered and cultured at early time points were irregular in shape and size. Initially this experiment used MacConkey agar without the TSA overlay. Recovery became increasingly lower as water temperatures dropped in the nutrient reservoirs due to changing seasons. E. coli will grow across the temperature range of 10 to $49^{\circ} \mathrm{C}$, but it will grow at a progressively slower rate when temperature is raised above $40{ }^{\circ} \mathrm{C}$ or below $20{ }^{\circ} \mathrm{C}$ (Cooper et al., 2001; Jones et al., 1987). Water temperature readings were below $20{ }^{\circ} \mathrm{C}$ for the early stages of the first two replications. E. coli was present (indicated by subsequent aliquots), but in low numbers and in some cases undetectable. A pre-enrichment step was deemed necessary to facilitate bacterial recovery (McKillip, 2001). In this case, it was the addition of TSA to the MacConkey plates in the form of an overlay. This gave injured bacteria an opportunity to repair themselves in the nutrient-rich environment and increased laboratory success in proper enumeration of E. coli (Smith et al., 2013).

Results for E. coli presence within the edible portions of lettuce were omitted from the statistical analysis due to the simplicity of the findings. An E. coli presence or absence screening was conducted on a total of 172 lettuce plants throughout the duration of the experiment. No contaminated plants were found, indicating that $E$. coli cannot be internalized from the rhizosphere into the root system growing in a hydroponic system. This evidence is contrary to that found by Solomon et al. (2002). The discrepancy of the before-mentioned study and this study could be the result of differing identification techniques. Solomon et al. (2002) used sophisticated microscopy for detection of bacterial internalization. They also grew plants in soil rather than a hydroponic system. However, this study is supported by Hora et al. (2005) who did not find internalization in aerial plant portions of spinach (Spinacia oleracea) when roots had been inoculated in soil containers.

Although mean separations were found at individual time points for lettuce growth and development parameters, the most important time point to address is $840 \mathrm{~h}$ (week 5). This time point reflects the most accurate time of maturation for 'Rex' lettuce and therefore conveys the most fundamental information to a grower considering the use of saponins in a recirculating hydroponic NFT system. Under every growth measurement, the noninoculated treatment without saponin addition and the inoculated treatment without saponin addition produced the highest yields on average. The fact that these treatments were the only 
treatments tested that did not include the saponin intervention indicates the economic impracticality of this treatment as a mitigation tool for E. coli or any other microbe when growing lettuce in an NFT system.

Reduced growth of lettuce was clearly related to an increase in saponin solution. It is difficult to say whether this reduced growth pattern was due to the active ingredient (steroid saponins) or other ingredients within the solution or a combination of these factors. The provided saponin solution used in this experiment is not currently on the market; however, there are similar products available to consumers from the manufacturer. These similar products are used as supplements for livestock feed to control ammonia and other noxious gasses in the immediate environment, conveying air-quality improvements. The formulation of the tested saponin extract product is not necessarily engineered for plant growth in a hydroponic NFT system.

The most likely cause of limited plant growth at higher concentrations of saponins is an increase in damaged plant cell membranes. Saponins are nonionic surfactants, which have phytotoxic effects on plant membranes by increasing permeability (Riechers et al., 1994). The damage caused to the root zone may have inhibited nutrient uptake and retarded the growth cycle.

Another postulate worth considering encompasses dissolved oxygen (DO) in the nutrient water. Unfortunately, due to equipment failures, DO was not measured across all replications of the experiment and therefore not included in the statistical analysis. Lettuce grows sufficiently at $\mathrm{DO}$ levels of at least $4 \mathrm{ppm}\left(4 \mathrm{mg} \cdot \mathrm{L}^{-1}\right)$ (Brechner et al., 2013). Using the limited measurements recorded and averaged over time in this study, DO levels are lower as higher saponin concentrations are added to the NFT system (Fig. 2). Levels did not fall below $4 \mathrm{mg} \cdot \mathrm{L}^{-1}$ until saponins were added at a concentration of 50 $\mu \mathrm{g} \cdot \mathrm{mL}^{-1}$ and above. Saponins are well-known for their ability to foam in aqueous solutions (Francis et al., 2002) as detergent-like compounds. Increased amounts of foam were observed at increasing saponin levels in this experiment. The amounts of foam were large enough to obstruct gas exchange between the nutrient reservoir of the NFT system and the atmosphere. A correlation cannot be stated, but appears to be consistent with DO levels, saponin treatment, and plant growth.

\section{Conclusions}

The primary objectives of this research study were to identify whether steroidal saponins from mojave yucca could be used as a natural bactericide for $E$. coli and what, if any, effects that would have on plant growth and development of 'Rex' lettuce grown in a hydroponic NFT system. The fact of the matter is that increasing saponin levels not only failed to elicit a bactericidal effect but promoted the growth of E. coli. All the while, plant health and vigor suffered in the presence of increasing amounts of saponin levels. Based on these results, this chemical intervention technique would not be recommended for the intended use of bacterial mitigation in hydroponic irrigation water.

Although data were not taken, another observation was that the saponin solution was rather unpleasant to work with because of a foul odor and equipment-clogging issues. Pumps and irrigation lines required extensive cleaning between experimental replications to prevent occlusions from manifesting.

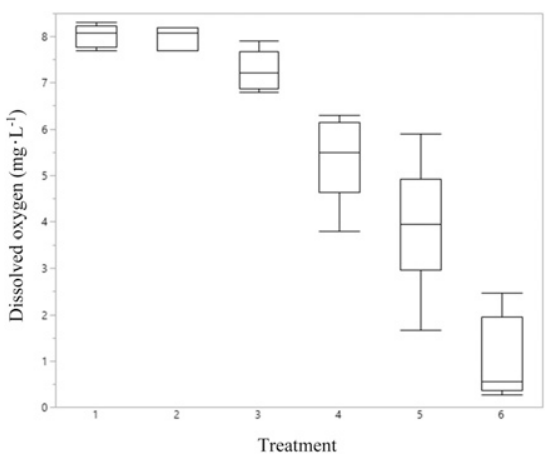

Fig. 2. Box and whisker plots of dissolved oxygen for individual saponin treatments in the nutrient film technique (NFT) system (unofficial). Treatment 1 = no Escherichia coli, no saponin addition; Treatment $2=E$. coli, no saponin addition; Treatment $3=E$. coli, 12.5 $\mu \mathrm{g} \cdot \mathrm{mL}^{-1}$ saponin; Treatment $4=E$. coli, $25 \mu \mathrm{g} \cdot \mathrm{mL}^{-1}$ saponin; Treatment $\mathbf{5}=$ E. coli, $50 \mu \mathrm{g} \cdot \mathrm{mL}^{-1}$ saponin; Treatment $6=E$. coli, $100 \mu \mathrm{g} \cdot \mathrm{mL}^{-1}$ saponin; $1 \mathrm{mg} \cdot \mathrm{L}^{-1}=1 \mathrm{ppm}, 1$ $\mu \mathrm{g} \cdot \mathrm{mL}^{-1}=1 \mathrm{ppm}$.
Another important takeaway was that E. coli does not appear to travel from the rhizosphere into the edible portions of lettuce plants by systemic means. E. coli also did not affect lettuce growth. In this study, the noninoculated treatment without saponin was juxtaposed to the inoculated treatment without saponin and found no differences in fresh shoot weight $(P=0.74)$. This indicates that $E$. coli living in the fertilizer solution and interacting with the vast community of microorganisms surrounding the root zone do not negatively impact the growth and development of 'Rex' lettuce in a hydroponic NFT system.

E. coli recovery was inadequate when using MacConkey agar growth media. Due to sublethal bacterial injury, a pre-enrichment step should be implemented in future research to ensure proper recovery and enumeration of bacteria. A TSA overlay on MacConkey agar was used in this experiment and is recommended for future study.

\section{Literature cited}

Arabski, M., A. Wegierek-Ciuk, G. Czerwonka, A. Lankoff, and W. Kaca. 2011. Effects of saponins against clinical E. coli strains and eukaryotic cell line. J. Biomed. Intl. 2012:286216: doi: 10.1155/2012/ 286216.

Belbahri, L., G. Calmin, F. Lefort, G. Dennler, and A. Wigger. 2007. Assessing efficacy of ultra-filtration and bio-filtration systems used in soilless production through molecular detection of Pythium oligandrum and Bacillus subtilis as model organisms. Acta Hort. 747:97-105.

Brechner, M., A.J. Both, and CEA Staff. 2013. Hydroponic lettuce handbook. 8 Dec. 2020 . <https://cpb-us-el. wpmucdn.com/blogs.cornell.edu/dist/ 8/8824/files/2019/06/Cornell-CEALettuce-Handbook-.pdf>.

Brown, A.G., D. Butterworth, M. Cole, G. Hanscomb, J.D. Hood, C. Reading, and G.N. Rolinson. 1976. Naturally occurring $\beta$-lactamase inhibitors with antibacterial activity. J. Antibiot. 29:668669, doi: 10.7164/antibiotics.29.668.

Centers for Disease Control and Prevention. 2019a. E. coli homepage. 21 Feb. 2020. <https://www.cdc.gov/ecoli/ 2019-outbreaks.html>.

Centers for Disease Control and Prevention. 2019b. Foodborne illnesses and germs. 24 Oct. 2019. <https://www.cdc. gov/foodsafety/foodborne-germs.html>. 
Centers for Disease Control and Prevention. 2017a. Diseases and conditions: Solve foodborne outbreak. 10 Nov. 2019. <https://www.cdc.gov/features/ solvingoutbreaks/index.html>.

Centers for Disease Control and Prevention. 2017b. Goods that sickened people in outbreak, 2009-2015. 10 Nov. 2019. <https://www.cdc.gov/foodsafety/pdfs/ foods-that-sickened-people.pdf $>$.

Cooper, V.S., A.F. Bennett, and R.E. Lenski. 2001. Evolution of thermal dependence of growth rate of Escherichia coli populations during 20,000 generations in a constant environment. Evolution 55:889-896, doi: 10.1111/ j.0014-3820.2001.tb00606.x.

Emmert, E.A.B. and J. Handelsman. 1999. Biocontrol of plant disease: A (gram-) positive perspective. FEMS Microbiol. Lett. 171:1-9, doi: 10.1111/ j.1574-6968.1999.tbl3405.x.

Francis, G., Z. Kerem, H.P.S. Makkar, and K. Becker. 2002. The biological action of saponins in animal systems: A review. Brit. J. Nutr. 88:587-605, doi: $10.1079 / \mathrm{BJN} 2002725$.

Garibaldi, A., A. Minuto, and D. Salvi. 2004. Disinfection of nutrient solution in closed soilless systems in Italy. Acta Hort. 644:557-562, doi: 10.17660/ ActaHortic.2004.644.74.

Haas, D., C. Keel, and C. Reimmann. 2002. Signal transduction in plant-beneficial rhizobacteria with biocontrol properties. Antonie van Leeuwenhoek 81:385-395.

Holvoet, K., I. Sampers, M. Seynnaeve, L. Jacxsens, and M. Uyttendaele. 2015. Agricultural and management practices and bacterial contamination in greenhouse versus open field lettuce production. Intl. J. Environ. Res. Public Health 12:32-63, doi: 10.3390/ijerph120100032.

Hora, R., K. Warriner, B.J. Shelp, and M.W. Griffiths. 2005. Internalization of Escherichia coli O157:H7 following biological and mechanical disruption of growing spinach plants. J. Food Prot. 69:2506-2509, doi: 10.4315/0362-028X-68.12.2506.

Jones, P.G., R.A. VanBogelen, and F.C. Neidhardt. 1987. Induction of proteins in response to low temperature in Escherichia coli. J. Bacteriol. 169:2092-2095, doi: 10.1128/jb.169.5.2092-2095.1987.

Khan, M.I., A. Ahhmed, J.H. Shin, J.S. Baek, M.Y. Kim, and J.D. Kim. 2018. Green tea seed isolated saponins exerts antibacterial effects against various strains of gram positive and gram negative bacteria, a comprehensive study in vitro and in vivo. Evid. Based Complement. Alternat. Med. 2018:3486106, doi: 10.1155/ $2018 / 3486106$.
Lokesh, R., V. Manasvi, and B.P. Lakshmi. 2016. Antibacterial and antioxidant activity of saponin from Abutilon indicum leaves. Asian J. Pharm. Clin. Res. 9:344-347, doi: 10.22159/ajpcr.2016.v9s3.15064.

Mandal, P., S.S. Babu, and N.C. Mandal. 2005. Antimicrobial activity of saponins from Acacia auriculiformis. Fitoterapia 76:462465, doi: 10.1016/j.fitote.2005.03.004.

Marshall, K.M., S.E. Niebuhr, G.R. Acuff, L.M. Lucia, and J.S. Dickson. 2005. Identification of Escherichia coli O157:H7 meat processing indicators for fresh meat through comparison of the effects of selected antimicrobial interventions. J. Food Prot. 68:2580-2586, doi: 10.4315/ 0362-028X-68.12.2580.

McKillip, J.L. 2001. Recovery of sublethally injured bacteria using selective agar overlays. Am. Biol. Teach. 63:184-188.

Njage, P. and E.M. Buys. 2014. Pathogenic and commensal Escherichia coli from irrigation water show potential in transmission of extended spectrum and AmpC $\beta$-lactamases determinants to isolates from lettuce. Microb. Biotechnol. 8:462473, doi: 10.1111/1751-7915.12234.

Oleszek, W. 1996. Saponins used in food and agriculture. Springer, Boston, MA.

Orozco, L., L. Rico-Romero, and E.F. Escartin. 2008. Microbiological profile of greenhouses in a farm producing hydroponic tomatoes. J. Food Prot. 71:60-65, doi: 10.4315/0362-028X-71.1.60.

Parnell, T.L., L.J. Harris, and T.V. Suslow. 2005. Reducing Salmonella on cantaloupes and honeydew melons using wash practices applicable to postharvest handling, foodservice, and consumer preparation. Intl. J. Food Microbiol. 99:59-70, doi: 10.1016/j.ijfoodmicro.2004.07.014.

Premuzic, Z., H.E. Palmucci, J. Tamborenea, and M. Nakama. 2007. Chlorination: Phytotoxicity and effects on the production and quality of Lactuca sativa var. Mantecosa grown in a closed, soil-less system. Phyton Intl. J. Expt. Bot. 76:103-117.

Riechers, D.E., L.M. Wax, R.A. Liebl, and D.R. Bush. 1994. Surfactant-increased glyphosate uptake into plasma membrane vesicles isolated from common lambsquarters leaves. Plant Physiol. 105:14191425, doi: 10.1104/pp.105.4.1419.

Shaw, A., K. Helterbran, M.R. Evans, and C. Currey. 2016. Growth of Escherichia coli O157:H7, non-O157 shiga toxinproducing Escherichia coli, and Salmonella in water and hydroponic fertilizer solutions. J. Food Prot. 79:2179-2183, doi: 10.4315/0362-028X.JFP-16-073.

Smith, A.R., A.L. Ellison, A.L. Robinson, M. Drake, S.A. McDowell, J.K.
Mitchell, P.D. Gerard, R.A. Heckler, and J.L. McKillip. 2013. Enumeration of sublethally injured Escherichia coli O157:H7 ATCC 43895 and Escherichia coli strain B-41560 using selective agar overlays versus commercial methods. J. Food Prot. 76:674-679, doi: 10.4315/ 0362-028X.JFP-12-363.

Soetan, K.O., M.A. Oyekunle, O.O. Aiyelaagbe, and M.A. Fafunso. 2006. Evaluation of the antimicrobial activity of saponins extract of Sorghum bicolor L. Moench. African J. Biotechnol. 5:2405-2407.

Solomon, E.B., S. Yaron, and K.R. Matthews. 2002. Transmission of Escherichia coli O157:H7 from contaminated manure and irrigation water to lettuce plant tissue and its subsequent internalization. Appl. Environ. Microbiol. 68:397-400, doi: 10.1128/AEM.68.1.397-400.2002.

Solomon, E.B., H.J. Pang, and K.R. Matthews. 2003. Persistence of Escherichia coli O157:H7 on lettuce plants following spray irrigation with contaminated water. J. Food Prot. 66:2198-2202, doi: 10.4315/0362-028X-66.12.2198.

Sturz, A.V. and B.R. Christie. 2003. Beneficial microbial allelopathies in the root zone: The management of soil quality and plant disease with rhizobacteria. Soil Tillage Res. 72:107-123, doi: 10.1016/S0167-1987(03)00082-5.

Symons, J.M., A.A. Stevens, R.M. Clark, E. Geldreich, O.T. Love, Jr., and J. DeMarco. 1981. Treatment techniques for controlling trihalomethanes in drinking water. EPA-600/2-81-156. Environ. Protect. Agency, Cincinnati, $\mathrm{OH}$.

Tiwari, B.K., V.P. Valdramidis, C.P. O’Donnell, K. Muthukumarappan, P. Bourke, and P.J. Cullen. 2009. Application of natural antimicrobials for food preservation. J. Agr. Food Chem. 57:59876000, doi: 10.1021/jf900668n.

Wallace, R.J. 2004. Antimicrobial properties of plant secondary metabolites. Proc. Nutr. Soc. 63:621-629, doi: 10.1079/ PNS2004393.

Wohanka, W. 1995. Disinfection of recirculating nutrient solutions by slow sand filtration. Acta Hort. 382:246-255, doi: 10.17660/ActaHortic.1995.382.28.

Zhu, M.J., S.A. Olsen, L. Sheng, Y. Xue, and W. Yue. 2015. Antimicrobial efficacy of grape seed extract against Escherichia coli O157:H7 growth, motility, and Shiga toxin production. Food Control 51:177-182, doi: 10.1016/ j.foodcont.2014.11.024. 